\title{
First record and a new species of Euphrosynoplax (Crustacea: Pseudorhombilidae) from the southwestern Atlantic
}

\author{
Marcos Tavares ${ }^{1}$ \& William Santana ${ }^{2}$ \\ 1 Universidade de São Paulo (USP), Museu de Zoologia (MZUSP). São Paulo, SP, Brasil. \\ ORCID: http://orcid.org/0000-0002-7186-5787.E-mail: mdst@usp.br (corresponding author) \\ 2 Universidade Regional do Cariri (URCA), Departamento de Ciências Físicas e Biológicas. \\ Crato, CE, Brasil. ORCID: http://orcid.org/0000-0003-3086-4419. E-mail: willsantana@gmail.com
}

\begin{abstract}
A new species of deep-water brachyuran crab, Euphrosynoplax dincao, from southeastern Brazil is described and illustrated. The genus Euphrosynoplax currently consists of two species, E. clausa Guinot, 1969, and E. campechiensis VázquezBader \& Gracia, 1991, both only known from the Gulf of Mexico. The new species can be easily separated from its northern counterparts by a suite of carapace and appendage characters. Euphrosynoplax campechiensis is recorded for the first time from the Caribbenan Sea (Guadeloupe and between Saint Kitts and Nevis).
\end{abstract}

Keywords. Taxonomy; Biodiversity; Brazil; Gulf of Mexico; Caribbean Sea; Deep-water.

\section{INTRODUCTION}

Euphrosynoplax Guinot, 1969, was established as a monotypic genus for E. clausa Guinot, 1969, from Dry Tortugas, Gulf coast of Florida. More than two decades elapsed before a second species of the genus was described, namely E. campechiensis Vázquez-Bader \& Gracia, 1991, also from the Gulf of Mexico. The genus currently consists of the above mentioned two species, both only known from the Gulf coasts (Vázquez-Bader \& Gracia, 1991; Ng et al., 2008; Felder et al., 2009).

Euphrosynoplax is now expanded to encompass a new species from much farther south, off the coast of southeastern Brazil. The new species is the first record of Euphrosynoplax from the southwestern Atlantic Ocean.

\section{MATERIAL AND METHODS}

The studied specimens are deposited either in the collections of the MZUSP (Museu de Zoologia, Universidade de São Paulo, Brazil) or USNM (National Museum of Natural History, Smithsonian Institution, Washington D.C.). Abbreviations used include: carapace length (cl), taken from the front to the posterior margin of the carapace; carapace width (cw), taken at the level of the third anterolateral tooth of the carapace; P1 cheliped; P2-P5, pereiopods 2 to 5; G1, G2, first and second gono- pod, respectively; stn, station; coll., collected by; F/V, fishing vessel; R/V, research vessel; don., donated by. Dates are written in the format day.month. year, with months in lower-case Roman numerals.

\section{RESULTS}

\section{Taxonomic account}

\section{Euphrosynoplax Guinot, 1969}

Type species: Euphrosynoplax clausa Guinot, 1969 , fixed by original designation and monotypy. Gender feminine.

Type locality: Florida, Dry Tortugas, 91 m.

Included species: Euphrosynoplax campechiensis Vázquez-Bader \& Gracia, 1991, Euphrosynoplax clausa Guinot, 1969, and Euphrosynoplax dincao sp. nov.

\section{Euphrosynoplax dincao sp. nov. (Figs. 1A-E; 2A, B; 3A, D, F)}

Type material: Brazil: holotype male, cl $48.5 \mathrm{~mm}$, cW 54 mm (MZUSP 25998), F/V “Daniela Moura I", stn $21,27^{\circ} 45^{\prime} 07.2^{\prime \prime} \mathrm{S} / 47^{\circ} 47^{\prime} 13.2^{\prime \prime} \mathrm{W}$, off the coast of Florianópolis, Santa Catarina, 19.iv.2008, bot- 
tom tangle net, $123 \mathrm{~m}$. 1 ovigerous female paratype cl $22.8 \mathrm{~mm}$, cW $31 \mathrm{~mm}$ (MZUSP 41475), same data as holotype.

Comparative material: Euphrosynoplax clausa: USA: holotype male, cl 24 mm, cw 33 mm (USNM 65938), Gulf of Mexico, Florida Keys, Dry Tortugas, south of Loggerhead Key, Tortugas Expedition Carnegie Laboratory, $24^{\circ} 40^{\prime} 12.0^{\prime \prime} \mathrm{N} / 81^{\circ} 34^{\prime} 48.0^{\prime \prime} \mathrm{W}, \mathrm{W}$.L. Schmitt coll.07.viii.1931, 91 m. 1 female (USNM 250197), Gulf of Mexico, R/V "Success", sth 23, from $29^{\circ} 44^{\prime} 55^{\prime \prime} \mathrm{N} / 87^{\circ} 11^{\prime} 53^{\prime \prime} \mathrm{W}$ to $29^{\circ} 48^{\prime} 58^{\prime \prime} \mathrm{N} / 87^{\circ} 02^{\prime} 35^{\prime \prime} \mathrm{W}$, F. Hubbard coll. 19.iv.1989. Euphrosynoplax campechiensis: USA: 1 male (USNM 298320), northern part of Gulf of Mexico, R/V "Oregon II", Cruise 210, stn 74, summer 1994. Caribbean Sea: 1 male (USNM 267608), between Saint Kitts and Nevis, R/V "Oregon II", stn 10843, 17 $06^{\prime} 00.0^{\prime \prime} \mathrm{N} / 62^{\circ} 316^{\prime} 48.0^{\prime \prime} \mathrm{W}$, U.S. Fish and Wildlife Service coll. 08.xii.1969, $589 \mathrm{~m}$. 1 female (MZUSP 29592), Guadeloupe, Mission ORSTOM-IRPM-SMCB, stn C32, west coast of Basse Terre, $16^{\circ} 21.34^{\prime} \mathrm{N} / 61^{\circ} 49.14^{\prime} \mathrm{W}, \mathrm{G}$. Leblond and J. Poupin coll. iv.1993, 350 m [J. Poupin don.].
Description of the holotype: Carapace (Fig. 1A-C; 2A, B) distinctly wider than long, maximal width at third anterolateral tooth, coarsely granular near anterolateral margins and frontal region, finely granulated posteriorly, central parts of carapace scarcely granulated. Carapace regions well marked. Ventrally, granulation neatly more distinct on suborbital, subhepatic, pterygostomial and branchiostegal regions. Pterygostomian region granular near dehiscense line and near mxp3. Branchiostegal region granular, pubescent. Fronto-orbital width little less than half of maximal width of carapace; frontal margin V-shape clefted medially; frontal margin coarsely crenulated; region behind frontal margin coarsely tuberculated. Supraorbital margin coarsely crenulated, interrupted by 2 distinct notches. Inner supraorbital tooth separated from front by wide, smooth, shallow gap; tooth broad triangular, coarsely tuberculated, blunt. Outer supraorbital tooth lobe-like, coarsely tuberculated. Suborbital margin lined with large tubercles, mesially with triangular, coarsely tuberculated tooth directed toward front, laterally with rounded lobe, V-shape notch between suborbital lateral lobe and outer orbital tooth. Anterolateral margin projecting in 4 coarsely tubercular teeth (outer or-

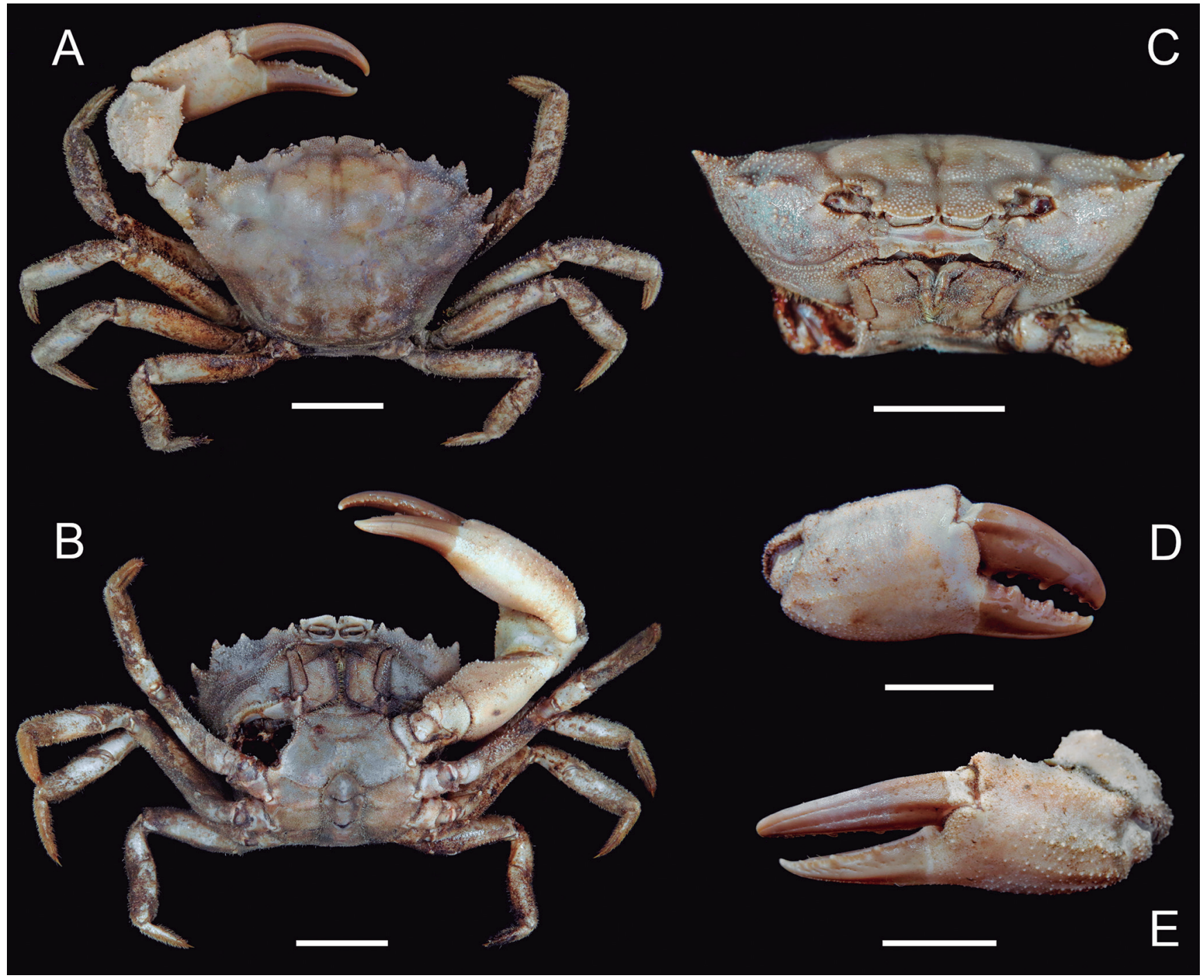

Figure 1. (A-E) Euphrosynoplax dincao sp. nov., holotype male, cl 48.5 mm, cw 54 mm (MZUSP 25998). (A, B) Habitus in dorsal and ventral view, respectively. (C) Anterior cephalothorax. Legs cropped electronically. (D, E) Right and left chelipeds, respectively, in lateral view. Scales: $15 \mathrm{~mm}$. 
bital excluded), increasing in size posteriorly from first to third tooth. First tooth straight, blunt; second largest, broad triangular, blunt, slightly curved forward; third curved forward; fourth spiniform. Gap between anterolateral teeth 2-3 distinctly wider than between teeth 1-2, 3-4. Posterolateral margin well defined, rather straight behind last anterolateral tooth, distinctly longer than anterolateral margin. Limit between epistome, endostome well defined, forming pronounced, sinuous lip, interrupted by 2 V-shaped notches, one at each side of shallow mesial notch.

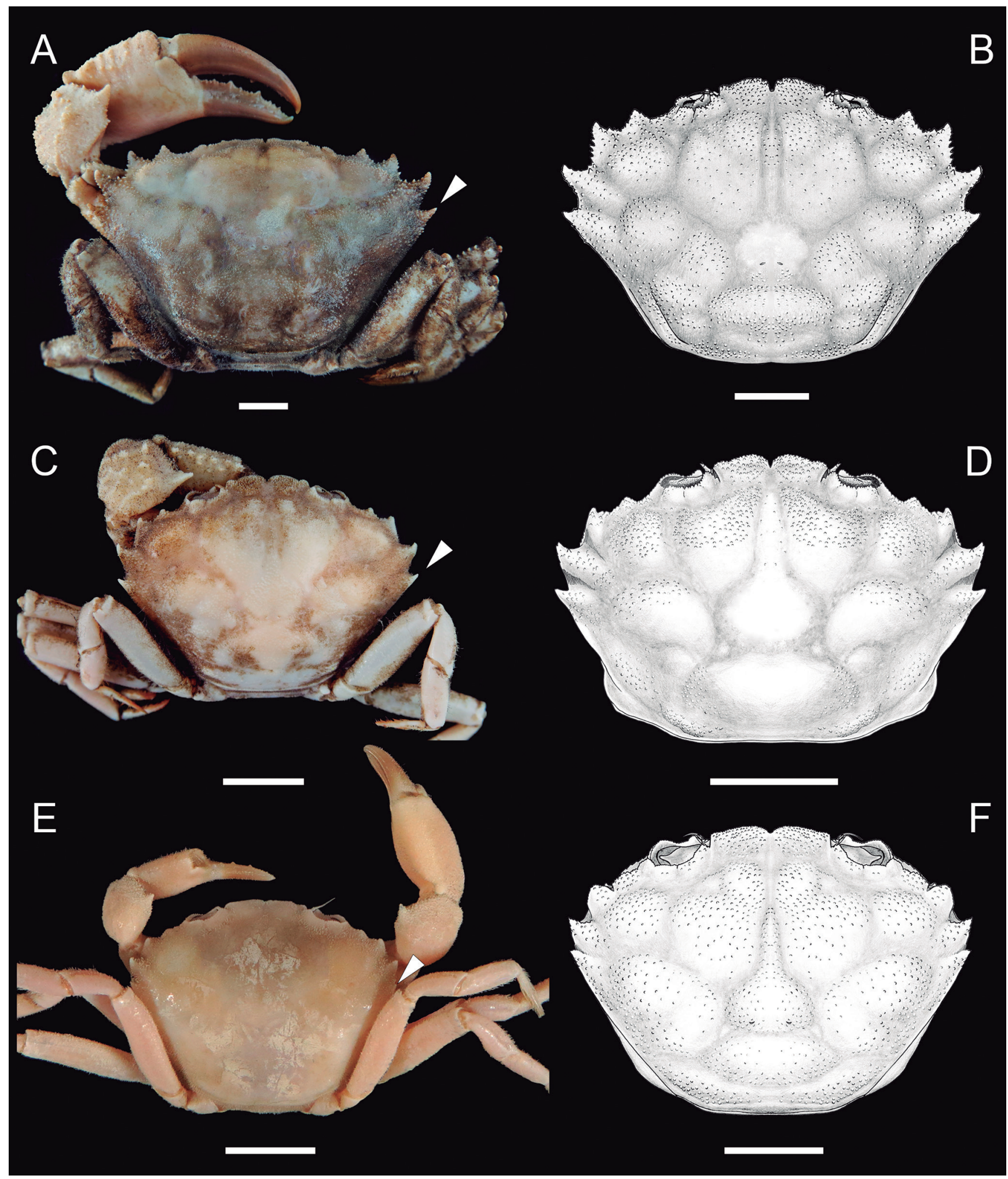

Figure 2. (A-F) Habitus and carapace in dorsal view. (A, B) Euphrosynoplax dincao sp. nov., holotype male, cl 48.5 mm, cw 54 mm (MZUSP 25998). (C, D) Euphrosynoplax campechiensis Vázquez-Bader \& Gracia, 1991, male, cl 24 mm, cw 32 mm (USNM 267608). (E, F) Euphrosynoplax clausa Guinot, 1969, male, cl 11 mm, cw 21 mm (USNM 250197). Arrows indicate the last (fourth) anterolateral carapace tooth. Note in (B) area behind the supraorbital margin distinctly granular and devoid of granules in (C, D). Pubescence not represented behind the supraorbital margin in (D). Note in (F) carapace appearing almost smooth to unaided eyes but provided with minute granules. Scales: $10 \mathrm{~mm}$. 

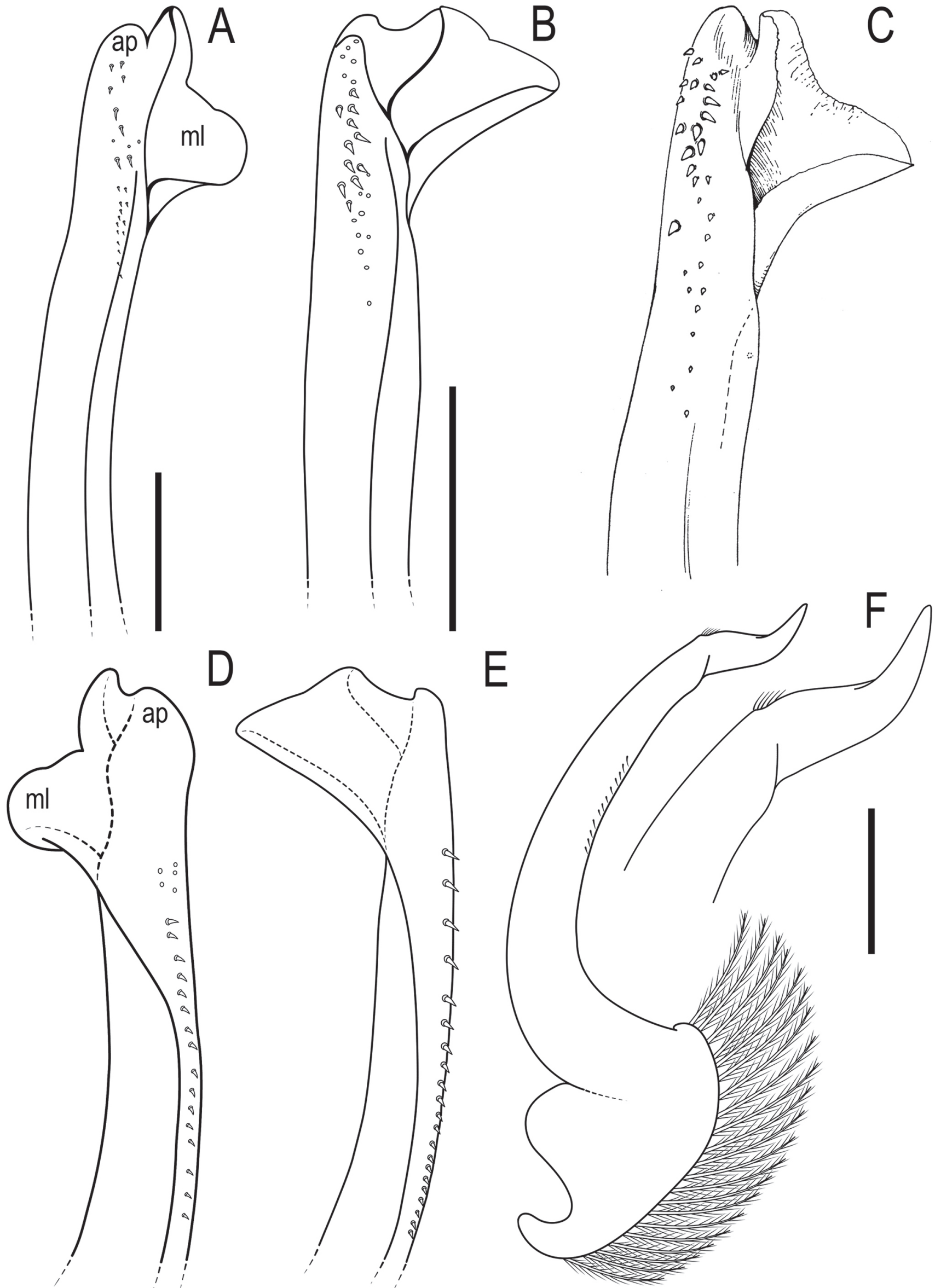

Figure 3. (A-E) First male gonopod in lateral (A-C) and mesial view (D, E). F, Second male gonopod in mesial view. (A, B, F) Euphrosynoplax dincao sp. nov., holotype, cl 48.5 mm, cw 54 mm (MZUSP 25998). (B, E) Euphrosynoplax campechiensis Vázquez-Bader \& Gracia, 1991, cl 22 mm, cw 31 mm (USNM 298320). (C) Euphrosynoplax clausa Guinot, 1969, holotype, cl 24 mm, cw 33 mm (USNM 65938) after Guinot (1969: 715, fig. 127). ap, apical lobe. ml, mesial lobe. Scales: 1 mm. 
Ocular peduncle (Fig. 1C) coarsely granular dorsally, freely movable, thick, fully retractable into large orbital cavity; cornea occupying little less than one-third of whole eye, brownish, ommatidia well recognizable.

Antennules prominent; basal article thickest laterally, with transverse row of coarse granules; second article smooth, elongate, subcylindrical, articulated to basal article at mesial end of antennular fossa; third article nearly equal in length to second, swollen distally, tapered to proximal articulation with second article, terminally with long stiff setae.

Antennal article $2+3$ immovable, filling orbital gap between strong, acute, inner orbital tooth and front; articles 4, 5 freely movable, subcylindrical. Thoracic sternum densely, evenly granular; lateral margins of sternites 2 to 4 coarsely granular. Sterno-pleonal cavity remarkably deep at level of sternites 4 to 6 , pilose, smooth anteriorly, lateral margins granular. Pleonal locking system functional, thoracic sternal button small, directed forward, placed about mid-length between thoracic sternal sutures 4/5 and 5/6.

Third maxillipeds (exopod included) (Fig. 1B, C) densely, evenly granular, granules larger near margins; palp finely granular.
Chelipeds heterochelous (Fig. 1D, E), left P1 strongest. Merus of major P1 trigonal, dorsal margin with row of spiny tubercles; lateral and ventral surfaces evenly covered with minute granules, and few scattered larger tubercles. Carpus with strong, blunt spine on inner margin; surfaces coarsely tubercular, tubercles of different sizes, spiny. Propodus stout, surfaces minutely granular. Fingers massive, gently curved inward, closing terminally only; cutting edges bluntly dentate, teeth of different sizes. Minor cheliped similar to major cheliped except for its less sout propodus and slender fingers.

Ambulatory legs (Fig. 1A, B), pubescent, rather, massive, similar to each other. Meri of P2-P5 spinulous dorsally and ventrally, granular laterally and mesially. Carpi of P2-P5 coarsely granular dorsally, otherwise smooth. Propodi of P2-P4 with scattered granular proximally; P5 propodus scattered granular dorsally. Dactyli of P2-P5 corneous-tipped, dorsal, ventral, lateral and mesial sides each with 2 longitudinal rows of long setae.

Pleon of 4 pleonites and telson. Pleonites 1-2 markedly shorts, coarsely granular, pubescent. Pleonite 1 slightly broader than pleonite 2. Pleonites 3-5 fused together; third coarsely granular proximally only, expanded lat-



Figure 4. (A, D) Euphrosynoplax campechiensis Vázquez-Bader \& Gracia, 1991, male, cl 24 mm, cw 32 mm (USNM 267608). (A, B) Habitus in dorsal and ventral view, respectively. (C) Anterior cephalothorax. (D) Left cheliped in lateral view. Scales: $10 \mathrm{~mm}$. 
erally, covering penis. Pleonites $4-6$ and telson rather smooth. Pleonal suture $3 / 4$ faint, still recognizable laterally; sutures $4 / 5$ and 5/6 indistinct. Pleonite 6 expanded anterolaterally. Telson semicircular.

G1 (Fig. 3A, D) curved towards inside sterno-pleonal cavity, slightly overreaching thoracic sternal suture 4/5; distal end with V-shaped, large lobe on sternal side. G2 (Fig. 3F) very short, about $1 / 4$ of the length of G1, strongly curved, tapering distally, ending in acute tip.

Female paratype resembling male, although much smaller. Pleon of 6 free, narrow pleonites and telson. Pleonites 1 to 5 of about same width and length; sixth pleonite almost twice as long previous pleonites. The paratype female carried numerous small eggs.

Etymology: We take great pleasure in naming this new species after our esteemed colleague and friend Fernando D'Incao (1947-2016), carcinologist and oceanographer at Universidade Federal do Rio Grande, Brazil. The specific name is used as a name in apposition.

Remarks: Euphrosynoplax consists so far of two species, both currently known from the Gulf of Mexico, namely E. clausa and E. campechiensis (Guinot, 1969; Vázquez-Bader \& Gracia, 1991; Felder et al., 2009).
Euphrosynoplax campechiensis is herein recorded for the first time from the Caribbean Sea (Guadeloupe and between Saint Kitts and Nevis- see above under material examined).

Euphrosynoplax dincao sp. nov. (Fig. 1A-E; 2A, B; $3 A, D, F)$ can be easily distinguished from the above two species in that the distal end of the male P5 merus falls short of the last (fourth) anterolateral carapace tooth or reaches to the base of the tooth at most, whereas in the northern counterparts the distal end of the male P5 merus extends almost to the tip of the last anterolateral carapace tooth (Fig. 2A-F). The three species also differ in the shape of the mesial lobe and development of the apical lobe of the G1 (Fig. 3A-E).

The new species is morphologically closer to E. campechiensis (Fig. 2C, D; 3B, E; 4A-D) of which it further differs in having the anterolateral teeth and anterolateral, pterygostomial and branchiostegal regions much more densely and coarsely tuberculated; the carapace front prominently protruded in ventral view (vs front distinctly less protruded in ventral view in E. campechiensis); and the area behind the supraorbital margin distinctly granular, devoid of tiny pubescence (vs area behind the supraorbital margin devoid of granules and with tiny pubescence in E. campechiensis).

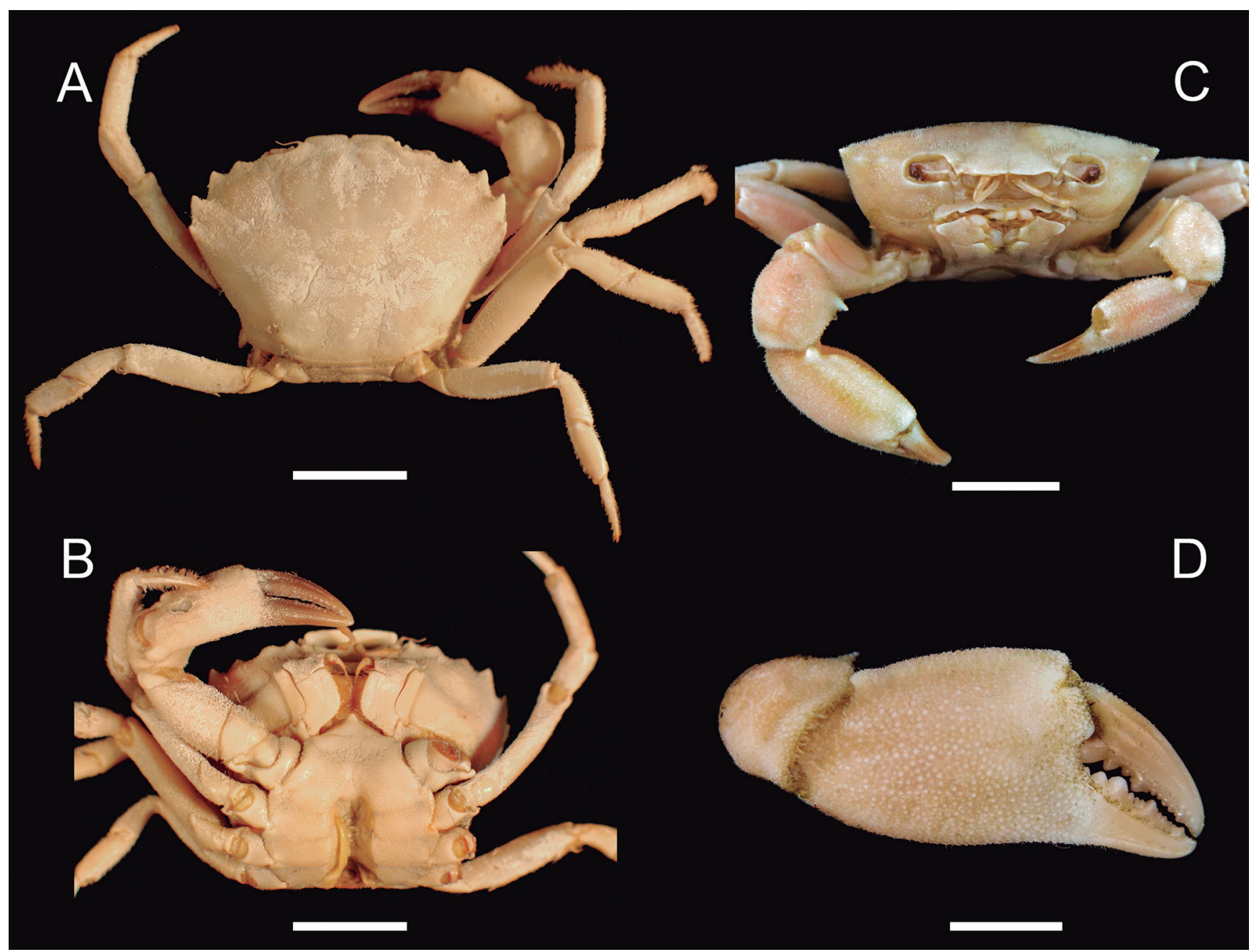

Figure 5. (A, D) Euphrosynoplax clausa Guinot, 1969. (A, B) Habitus, dorsal and ventral view, respectively, holotype male, cl $24 \mathrm{~mm}$, CW 33 mm (USNM 65938). (C, D) Anterior cephalothorax and right cheliped in lateral view, male, cl $11 \mathrm{~mm}, \mathrm{cw} 21 \mathrm{~mm}$ (USNM 250197). Scales: A-C, $10 \mathrm{~mm}$; D, $0.5 \mathrm{~mm}$. 
Euphrosynoplax dincao sp. nov. additionally stands apart from E. clausa (Fig. 2E-F; 3C; 5A-D) in having the carapace and appendages unevenly tubercular with tubercles of different sizes (vs carapace and appendages more evenly and finely granular); carapace regions well marked (vs carapace regions faintly marked in E. clausa); last (fourth) anterolateral tooth large and more laterally directed (vs last carapace tooth much smaller and more forward directed in E. clausa); orbits, almost completely filled by the ocular peduncle, orbital cavity smooth (vs orbits distinctly larger than the ocular peduncle, upper region inside the orbital cavity granular in E. clausa); and the frontal margin, bilobed, V-shaped incised, each lobe with a lateral prominence (vs frontal margin much less prominent, U-shaped incised, each lobe only gently prominent laterally in E. clausa).

The north-south disjunct distribution pattern of Euphrosynoplax is highly comparable to those of other moderately deep-water decapods, such as Eumunida, Neopilumnoplax, Robertsella, Speocarcinus and Trichopeltarion (Brandão et al., 2010, 2012; Tavares \& Melo 2005, 2010; Tavares \& Gouvea, 2013; Tavares \& Lima 2019). Such distribution gaps may well be only the result of poor distributional information and detectability, as exemplified by the deep-water genus Chaceon, whose fragmented distribution of some of its southwestern Atlantic representatives has been slowly filled as a result of the intensification of deep-water commercial fishing and detection facilitated by the species' large size (Manning \& Holthuis, 1989; Manning et al., 1989; Tavares \& Pinheiro, 2011).

\section{ACKNOWLEDGEMENTS}

We are grateful to Rafael Lemaitre (USNM) for making material from his institution available for study and for providing working space and to Karen Reed (USNM) for her kind assistance during our visit. Thanks also to Laira Lianos and Michele Mollemberg (UNESP, Botucatu) for preparing the photographs and Jessica Colavite (MZUSP) for preparing the figures for this study. MT thanks CNPq (Conselho Nacional de Desenvolvimento Científico e Tecnológico - Brazil) (Produtividade, \#309488/2020-6) for supporting studies on the systematic of decapod crustaceans. WS thanks CNPq (PQ2 \#315185/2020-1) and the Fundação Cearense de Apoio ao Desenvolvimento Científico e Tecnológico FUNCAP (fellowship \#6647309/2017).

\section{AUTHOR'S CONTRIBUTIONS}

Both authors contributed equally to this manuscript.

\section{REFERENCES}

Brandão, M.; Tavares, M. \& Coelho Filho, P.A. 2010. A new species of Speocarcinus Stimpson, 1859 from the southwestern Atlantic (Decapoda: Brachyura: Xanthidae). Nauplius, 18(2): 137-142.

Brandão, M.; Coelho Filho, P.A. \& Tavares, M. 2012. A review of the genus Speocarcinus Stimpson, 1859 (Crustacea: Brachyura: Xanthidae), with a key to its species and the description of one new species. Zootaxa, 3327: 1-19.

Felder, D.L.; Álvarez, F.; Goy, J.W. \& Lemaitre, R. 2009. Decapoda (Crustacea) of the Gulf of Mexico, with comments on the Amphionidacea. Chapter 59. In: Tunnell, Jr. J.W.; Felder, D.L. \& Earle, S.A. (Eds.). Gulf of Mexico Origin, Waters and Biota, vol. 1. Biodiversity. Texas A\&M University Press, College Station, pp. 1019-1104.

Guinot, D. 1969. Recherches préliminaires sur les groupements naturels chez les Crustacés Décapodes Brachyoures. VII. Les Goneplacidae. Bulletin du Muséum national d'Histoire naturelle, sér. 2, 41(3): 688-724.

Manning, R.B. \& Holthuis, L.B. 1989. Two new genera and nine new species of geryonid crabs (Crustacea, Decapoda, Geryonidae). Proceedings of the Biological Society of Washington, 102(1): 50-77.

Manning, R.B.; Tavares, M. \& Albuquerque, E.F. 1989. Chaceon ramosae, a new deep-water crab from Brazil (Crustacea: Decapoda: Geryonidae). Proceedings of the Biological Society of Washington, 102(3): 646-650.

Ng, P.K.L.; Guinot, D. \& Davie, P.J.F. 2008. Systema Brachyurorum: Part I. An annotated checklist of extant brachyuran crabs of the world. The Raffles Bulletin of Zoology, 17: 1-286.

Tavares, M. \& Melo, G.A.S. 2005. A new species of Trichopeltarion A. MilneEdwards, 1880, from the Southwestern Atlantic (Crustacea: Brachyura: Atelecyclidae). Papéis Avulsos de Zoologia, 45(18): 235-242.

Tavares, M. \& Melo, G.A.S. 2010. A new species of Neopilumnoplax Serène in Guinot, 1969 (Decapoda, Brachyura, Mathildellidae) from the southwestern Atlantic. Crustaceana Monographs. Studies on Malacostraca, 14: 685-691.

Tavares, M. \& Pinheiro, A.P. 2011. A new species of Chaceon Manning \& Holthuis, 1989, from the southwestern Atlantic, with a key to the western Atlantic species (Crustacea, Decapoda, Geryonidae). Zootaxa, 3086: 57-68.

Tavares, M. \& Gouvea, A. 2013. A new species of Robertsella Guinot, 1969 (Crustacea: Brachyura: Panopeidae) from the southwestern Atlantic. Zootaxa, 3734(1): 72-80.

Tavares, M. \& Lima, D. 2019. First record of the genus Eumunida Smith, 1883 (Crustacea, Decapoda, Eumunididae) from the southwestern Atlantic, with the description of a new species. Papéis Avulsos de Zoologia, 59: 1-10.

Vázquez-Bader, A.R. \& Gracia, A. 1991. Euphrosynoplax campechiensis, new species (Decapoda, Brachyura, Goneplacidae), from the continental shelf of the Southwestern Gulf of Mexico. Bulletin du Muséum national d'Histoire naturelle, sér. 4, section A, 13(3-4): 688-724. 